\title{
Foreign direct investment in the Republic of Serbia: Correlation between foreign direct investments and the selected economic variables
}

\author{
László Vasa \\ Kautz Gyula Faculty of Economics, Széchenyi István University \\ Hungary \\ laszlo.vasa@ifat.bu
}

\author{
Aleksandra Angeloska \\ Faculty of Economics and Social Sciences, Szent István University \\ Hungary \\ angeloska1@,live.com
}

Abstract. Foreign Direct Investment (FDI) in the theory of economic thought is considered to be an important factor for country's growth and development. By encouraging multinational corporations to invest, host countries hope to generate spillovers because FDI transfer intangible assets to the affiliate, which may then diffuse to local firms. Serbia is integrating into European economic space with a significant delay. Despite a thunderous decade of wars and ethnic tussle, late transition and financial crisis, Serbia has experienced significant FDI inflows in the last decade, mainly because of the improved policies attracting foreign investors. The aim of this paper is to analyze the correlation and significant degree to which the examined variables are associated with each other. The economic variables cover 12 years (20072018). The main focus is on those variables that are considerably influencing changes and impact on FDI in Serbia. The study uses SPSS to analyse the correlations among the selected eight socioeconomic variables. The examined variables are: industrial growth, unemployment rate, employment from age 15 to 65, foreign trade balance, FDI inflows, FDI outflows, GDP growth, and the share of value added products in the exports. For this analysis the data from the Statistical Office or the Republic of Serbia, the National Bank of Serbia and the Ministry of Finance has been used. There is a very weak correlation between FDI inflows and the unemployment rate. Also, our results suggest there is a very weak correlation between FDI inflows and increased GDP growth. The GDP growth has strong correlations with the industry growth, FDI inflow and FDI outflow.

Keywords: FDI inflow and outflow, GDP growth, employment, trade balance, Serbia. 
JEL Classification: E22, E24, F21, F23

\section{INTRODUCTION}

Increased globalization leads to increased economic interdependence of countries and the physical distance is losing its meaning. As defined by the International Monetary Fund (IMF), foreign direct investment (hereinafter FDI) is a category of international investment that reflects the objective of the resident company of an economy to acquire a long-lasting interest in a company that is resident in another economy (IMF, 2009). Countries around the globe are actively attracting FDI. It is assumed that FDI bring external effects that have positive impact on productivity levels in a host country (Bilan et al. 2019).

FDI adds directly to employment, capital, exports, and new technology in a host country (Blomström et al., 2000). These externalities are commonly known as spillovers. These spillovers arise because multinational corporations (hereinafter MNCs) possess firm-specific assets (hereinafter FSA) (Markusen, 2004). These firm-specific assets could be superior production techniques (Nagy et al. 2018), knowhow or management strategy, they have at least some of the characteristics of a public good and enable the firm to locate profitably abroad (Caves, 1996). At the same time, FDI contribute to creation of new jobs and training of the employed people, and this contributes to increasing productivity (Bobenič Hintošová et al, 2018). Furthermore, FDI represents a method for financing the deficit of the country's current account, which is very crucial in cases when the deficit is unsustainable. FDI can be essential in the field of green investments (Lyeonov et al. 2019). Literature review supports the theory that FDI has positive impact on growth. Reisen and Soto (2001) Vasylieva et al. (2019) report that FDI inflows boost growth, Basu and Guariglia (2007) found there is a positive correlation between FDI and GDP growth in 119 countries.

FDI entry into transition countries brings capital, technology, know-how, maintenance and development of their international competitiveness (Zugic, 2011; Tung, 2019). However, the level of realized FDI in a country depends on many factors: social inequalities (Fazaalloh, 2019), geographical position, environment stability, political and economic freedom and risk, access to local and regional markets, legal security, working strength and institutional building in a country (Ibreljić \& Nuhanović, 2011).

FDI is the biggest developmental opportunity of companies from the Western Balkans and the best way to increase production, employment, export and living standards in the long term. Serbia started its transition back in 1989 after the fall of communism, when it was still part of socialist Yugoslavia. It is an interesting case and a country with maybe most complex transition process of more than 20 years. The last event was the unilateral separation of the southern province of Kosovo. Multiple political events in the course of 20 years had negative impact on the economy. In the meantime, a substantial improvement took place in Serbia's political relations with the European Union (hereinafter EU), leading to the signing of a Stabilization and Association Agreement in 2008 and Serbia's application for the EU candidate status (Uvalic, 2011).

In the last several years, Serbia was successful in attracting FDI due to the economic reforms it has undertook. The country has still plenty to implement, in terms of improvement of tax administration and interpretation of tax regulation. There are some cases which should be analysed for a proper investment policy in the country (see the case of Romania; Simionescu, 2016; 2018).

The objective of this study is to investigate the relationship between FDI and the selected socioeconomic variables in the period of 2007-2018. The findings of this study will provide directions for government officials and policymakers on how to manage macroeconomic variables and economic 
policies to promote the economic sector through FDI. Further, the findings could be used as an example for other developing countries similar to Serbia economic characteristics.

\section{LITERATURE REVIEW}

In order to examine the effects of FDI on the main macroeconomic indicators of Serbia, first it is necessary to gain insight into the movement of these indicators. Statistical Office of Serbia (SORS) in 2019 publishes preliminary results of the revision of gross domestic product (GDP) according to the European Systems of Accounts 2010 methodology and based on the production and expenditure approach, at current and constant prices. When analyzing GDP in Serbia, it is inevitable to mention the economic sanctions that had a very negative impact on the economy. After 2000, the Serbian government undertook major economic reforms. The goal of the reform was formation of a market-based and open economy, which up to the Financial Crisis contributed for rising economic growth rates.

The Financial Crisis had its effect also on the Serbian economy, where GDP was decreasing until 2010. In 2010 there is a positive growth compared to 2009, which continued until end of 2011. In the following years, between 2012 and 2014, GDP growth was moving from $-0.7 \%$ to $-1.6 \%$. After 2015, the GDP is in continuous growth and reached $4 \%$ in 2019 . Observed by activity, in 2019, the most significant share in the formation of GDP was the manufacturing sector amounting for $15.1 \%$, followed by the wholesale and retail trade and repair of motor vehicles $11.4 \%$, real estate sector $7.3 \%$, the agriculture, forestry and fishing sector $6 \%$, and the information and communication sector $5 \%$. On the other hand, in the use of GDP, the share of expenditures for personal consumption of households is $69.6 \%$, expenditures for final government consumption 16.2\%, gross fixed capital formation 17.7\%, exports of goods and services 50.5\% and import of goods and services 57.1\% (SORS, 2019).

Industrial production is a significant area of the economic policy of each country, as on it depends growth, employment, maintaining foreign economic balance in exports and imports. Draskovic (2014) explains that prior de-industrialization in Serbia there were 217 big companies, unlike 55 in 2012. However, industrial growth in Serbia remains on a very low level, despite multiple strategies prepared by Serbian government in 2010. Serbian business model needs to change, in an era of "Industry 4.0". There is a need of new business culture that requires knowledge and specific skills competences.

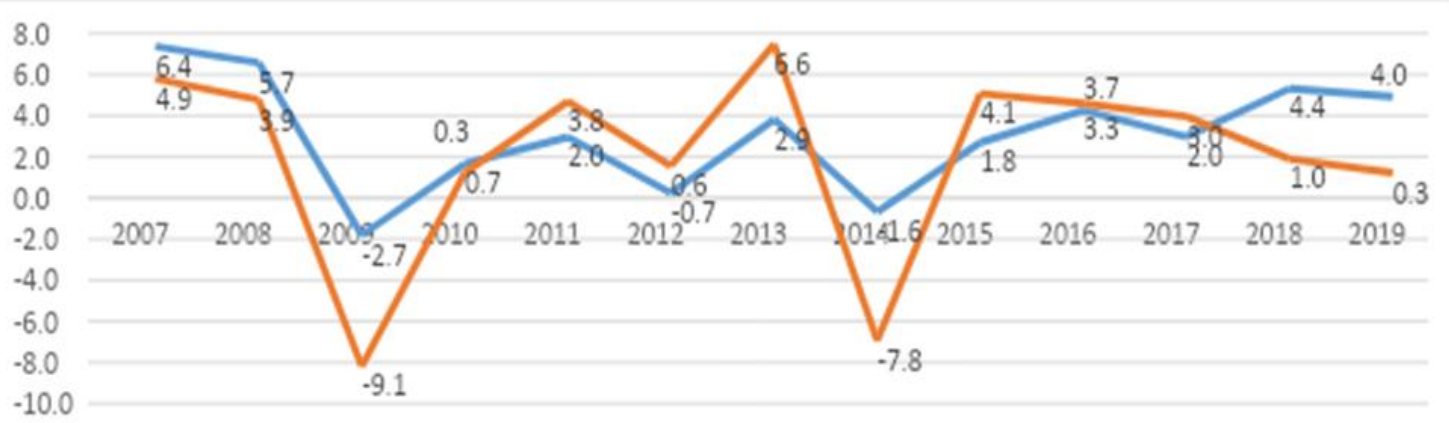

- GDP growth - Industrial growth (Rate of growth of industrial gross value added)

Figure 1. GDP growth and Industrial growth (in \%) in Serbia, 2007-2019 Source: SORS and Ministry of Finance, 2019

Serbia ranks first in the world by number of jobs opened through FDI in relation to the country's population indicated by the new IBM Report (2018). In 2017, in total there were 353,469 new jobs created 
from the FDI in Europe. This means 19\% increase of jobs compared to 2016. Out of the total number of newly created jobs, $6 \%$ or 20,103 new jobs were created in Serbia. The IBM Report (2018) also shows that almost $80 \%$ of the total jobs created through FDI fall on production activities.

The World Bank and the Vienna Institute for International Economic Studies Report (2019) shows that labor market continues to improve. According to it, unemployment in 2018 declined again, to an estimated annual average of $12.7 \%$ and employment rose by $0.9 \%$ points compared to 2017 , which suggests that 38,275 more jobs were created in 2018. As a result, employment among the population over 15 years old reached a record high of $47.6 \%$, and average wages went up by 4.4 percent in real terms (SORS, 2019). Critics of the government and the intellectuals in Serbia, often emphasize that the decreased unemployment rate is not real, as it is mainly impacted by the emigration from Serbia.

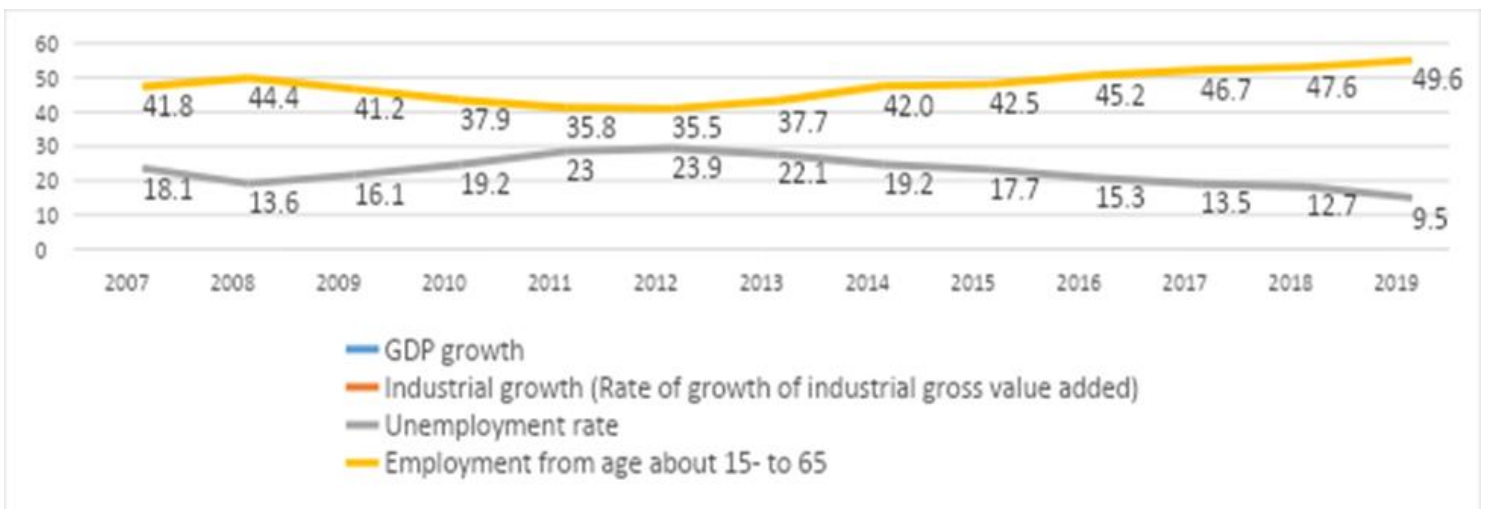

Figure 2. Unemployment rate (in \%) and employment aged 15-65 (in \%) in Serbia, 2007-2019 Source: SORS, 2019

Analyzing the FDI in Serbia, in the period from 2007 until 2018, according to the National Bank of Serbia (NBS) (2019), it is visible from Figure 4 that FDI inflows were in fall until 2010, which is due to the financial crisis and its impact to Serbian economy. In the examined period important FDI were realized, such as the privatization of the mobile operator "Mobtel" that was bought by the Norwegian company "Telenor", but also greenfield investments such as "Vip Mobile", "Microsoft's Development Center" and "Ball Packing". Most significantly the year 2008 saw the takeover of "Zastava" car manufacturing by "FIAT" with an unprecedented investment project worth EUR 940 million. In 2014, according to UNCTAD (2014), Serbia was in the top 5 host economies for FDI inflows and remained the largest recipient of FDI flows in Western Balkans, at USD 2 billion. "IKEA" investment in Serbia was the biggest greenfield investment, a Swedish company operating in consumer products and furniture sector. Its estimated capital expenditure was USD 373 million and this greenfield investment created almost 2,800 new jobs (UNCTAD, 2014).

In 2016, the interest of Chinese investors was on the rise. The state-owned company "Hebei Iron and Steel Group" acquired Serbian state-owned enterprise "Zelezara Smederevo" resulting in FDI positive inflow, but it is worth mentioning that most of it was realized through reinvested earnings in and intracompany loans to foreign affiliates (UNCTAD, 2018).

According to UNCTAD (2018), in 2016 FDI grew by 22\%, to USD 2.9 billion, mostly through reinvestment in existing foreign affiliates. The following 2017, Serbia had an increase in value of the inflow by $22 \%$ and increased its share in the total world investment inflow from $0.13 \%$ to $0.2 \%$. 


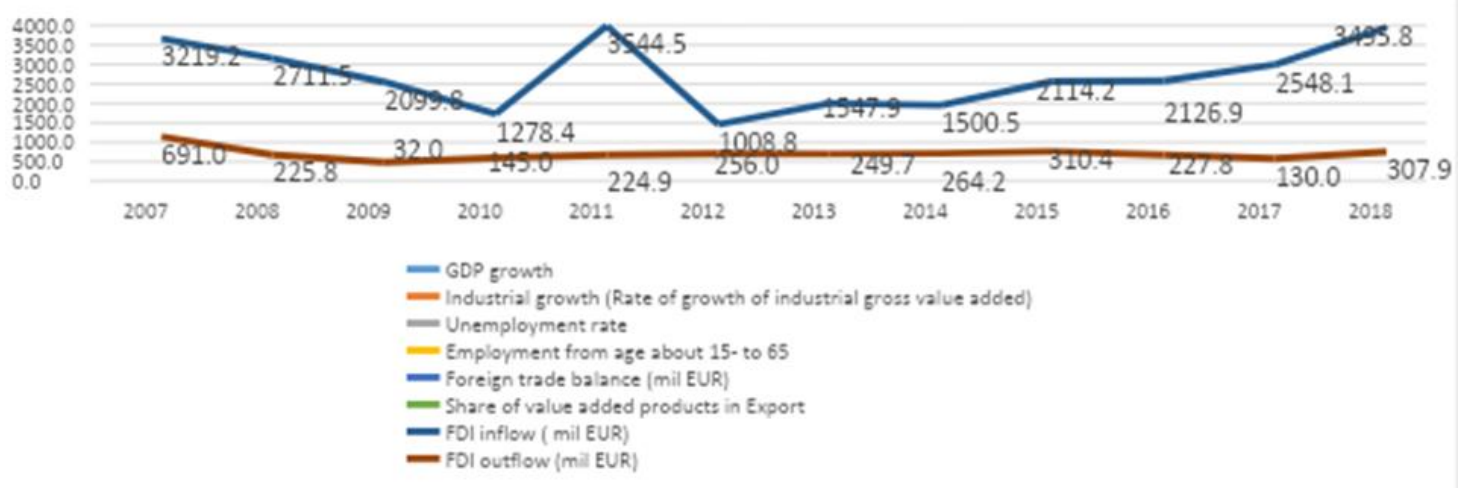

Figure 3. FDI inflow and outflow, in mil EUR, in Serbia, 2007-2018 Source: NBS, 2019

According to SORS (2019), the country attracted 12 times more greenfield FDI in 2016 than would be expected for the economy of this size. According to Ernst and Young (2018), in Central Europe, Serbia is second most desirable region for investment on the European continent. However, tight labor markets and rising wages are reason for stalling FDI, as companies there move up the value chain. Therefore, investment in labor-intensive projects shifts to Serbia, Russia and Turkey. In 2017, again Serbia was among top five FDI inflows host economies among the transition economies (UNCTAD, 2018), attracting 118 FDI projects, which compared to 2016 is $157 \%$ more.

Latest report from UNCTAD (2019) shows that FDI inflows in Serbia in 2018 grew by $44 \%$. Due to the fact that Serbia's economy is the largest in the Western Balkans, relatively diversified and due to its strategic location, facilitates many logistics investment such as the "Vinci Airports" (France) stake in "Nikola Tesla Airport" in Belgrade. Its natural resources (especially copper) are also attracting resourceseeking firms. The "Zijin Mining Group" (China), for example, acquired "RTB Bor" copper mine. FDI in Serbia's growing automotive cluster (e.g. the projects of the United Kingdom-based wire producer "Essex Europe" and Japan-based cable producer "Yazaki") benefits from the country's skilled labour force. Finally, the country's knowledge base is attracting R\&D centers, such as German tire maker "Continental" in Novi Sad.

During the examined period Serbia has continuous deficit, realizing more imports than exports. Serbia's biggest deficit is with China (due to imports of phones for cellular networks and laptops) and the Russian Federation (due to the import of energy products, primarily oil and gas).

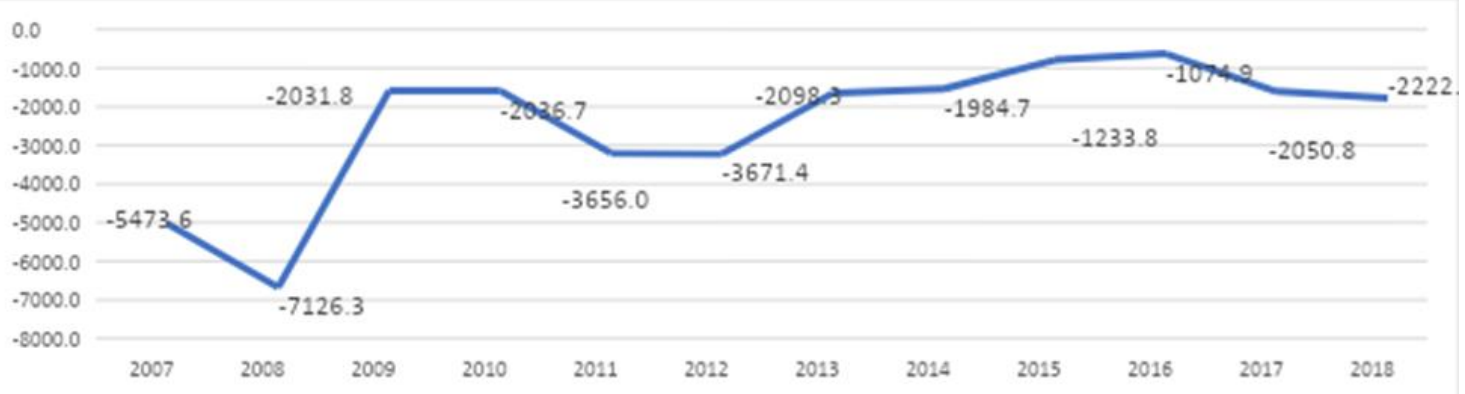

Figure 4. Foreign trade balance (mil EUR) in Serbia, 2007-2018

Source: NBS, 2019 
Main foreign export partners of Serbia were Germany, Italy, Bosnia and Herzegovina, Romania and Russia, while and imported from Germany, Russia, China, Italy and Hungary. The second most important trading partner of Serbia are the CEFTA countries, which is mainly the result of agricultural products (cereals and products thereof), road vehicles, iron and steel, electric machines and appliances and oil, and petroleum products (SORS, 2019).

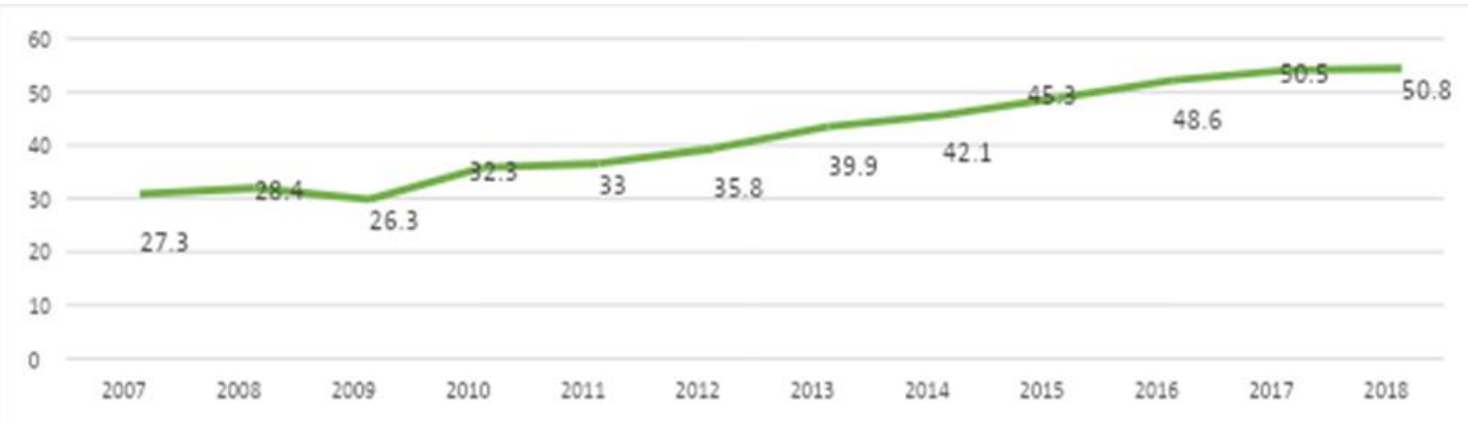

Figure 5. Share of value added products in Export, in Serbia, 2007-2018

Source: NBS, 2019

The most important reasons for Serbia's recent success in attracting FDI are economic reforms. Among these reforms is shortening the time required for registering a company registration, but also shortening time for issuing construction permit, which tales only 11 days.

\section{METHODOLOGY}

The aim of the paper is to analyze the correlation and significant degree to which the examined variables are associated with each other. The economic variables are the features of 12 years (2007-2018). Main focus is on those variables that are considerably influencing changes and impact on the FDI in Serbia. The study uses the SPSS (Statistical Program for Social Sciences) statistical system to analyse the correlations among selected eight socio-economic variables. Examined variables are: industrial growth, unemployment rate, employment from age 15 to 65, foreign trade balance, FDI inflows, FDI outflows, GDP growth, and share of value added products in the exports.

In the following paragraphs are described the significance of the eight variables used for this research. In order to proxy market size and level of competition, author used GDP growth of Serbia. The data used is from The State Statistical Office. The volume of FDI in a given country depends on the market volume, which can be measured through the total output of the FDI or host country`s GDP growth (Deluca, 2004). Assuming that FDI are increasing over the examined period, we are expecting that there will be positive effect from the trend. This research can be tested on different levels in separate economies of FDI investment. Therefore, GDP growth was used, as most reliable variable to show the correlation between FDI market size and the economy growth (Melitz - Ottaviano, 2008). Many empirical research lead to positive correlation between the FDI in the host country and host country`s GDP growth. As the level of GDP per capita in a country is correlated with many factors, it may reflect these other factors instead.

Industrial growth is shown as rate of the growth of industrial gross value added and date is extracted by both State Statistical Office and Ministry of Finance. Theoretically, FDI stimulates host country industrial growth by transferring technology and restructuring industrial sector. According to RodríguezClare (1996), the variety of specific inputs and the relative strength of the competition determine the 
impact of FDI on the domestic industrial sector. FDI effect on the industry growth is twofold: the linkage effect and the competition effect. Linkage effect on industrial sector of host country occurs when the production of investing foreign firms depends on intermediate goods produced by local firms. Because of product competition, foreign firms may force domestic firms to exit the market.

Therefore, the interdependencies between the FDI and the labour market related aspects are an important topic when examining impact of the FDI. An important number of specialists argue that countries with higher unemployment rates have two major advantages in the eyes of foreign investors: a) plenty of available labour force; b) high probability of finding available work force at lower wages (Blanchard, 2011). For this research the unemployment rate data was obtained by the State Statistical Office, based on revised data on employment (Labour Force Survey data) from 2014.

In an important part of similar studies (Botric \& Skuflic, 2006), the employment or the unemployment is used as a proxy for the macroeconomic stability of a country. In this paper, we used as variable the employment from age 15 to 65 in Serbia, because it is clear that the interdependencies among FDI and the employment or the unemployment rate can vary significantly from country to country and also from period to period (Strat et. al., 2015).

The effect of FDI on trade has also become a concern of policymakers. For most developing and transition countries such as Serbia, the relationships between foreign trade and FDI are at the heart of their economy. Open economies such as Serbia, today react differently to relative price shocks, or demand and supply factors. In particular, the development of international production networks and related FDI flows has increased the import content of export production. While they enjoy the benefits of the processing trade regime, of policies designed to promote FDI and of special economic zones, most developing countries still face balance of payments problems in conjunction with their export-oriented growth (Soukiazis \& Cerqueira, 2012). The paper aims to analysis whether foreign trade balance is linked to FDI inflows and outflows. Data for these variables were extracted by National Bank of Serbia and calculated as: Foreign Trade Balance $=$ Trade of goods and services - Current account balance.

Domestic value added in a country's exports indeed represents an important measure of income from trade and thus acts as an important guideline for development policy (Caraballo and Jiang, 2016). Namely, the high country's volume of exports is not necessarily reflected in its economic growth as it was in the past, since only the domestic part of the country's total exports contributes to its GDP (UNCTAD, 2013). In fact, the creation of value-added products has usually involved the prevailing FDI undertaken by transnational corporations. For instance, UNCTAD (2013) identified the statistical relationship between FDI in countries and their participation in the value chains. Under this context, in this paper we examine whether the FDI has really led to growth of share of value-added products in Serbian export. Data was collected by the State Statistical Office.

Recent studies by Herzer (2008) for industrialized countries suggest significant and positive effect of FDI outflows on domestic output in the long run. On the other hand, Ameer and $\mathrm{Hu}$ (2017) found positive and significant impact of FDI outflows and inflows on economic growth in the long run among developing economies. The effects of inward and outward FDI may differ between developed and developing countries. In case of Serbia, aim of the research is to find whether there is positive or negative correlation and impact on the selected economic variables. Statistical data was retrieved from National Bank of Serbia as balance of payment.

In the research two tests that indicate the suitability of the data for structure detection was applied. The Kaiser-Meyer-Olkin Measure of Sampling Adequacy (KMO) showing 0.423 value of for which value is needed at least above $0.500(50 \%)$, indicating that the factor analysis will not be very useful for the research. The Barlett's Test was used too, it shows 0.000 value of significance, making it best for 
analysing. As Chi-Square has value higher than 0.600 , together with the result of significance show that the data base collected and used for this analysis, using SPSS, is adequate for the research.

Therefore, Anti-image Matrices was applied to measure the significance level for each economic variable covered in this analysis. The most significant variables are FDI inflow with $0.842(84.2 \%)$ and GDP growth with 0.575 (57.5\%). Foreign Trade Balance with $0.480(48 \%)$ and Industrial Growth with $0.475(47.5 \%)$ are below the significance level of $50 \%$, but these economic variables have significance for the analysis. In addition, Total Variance Explained method was performed and the cumulated value is 84,392 showing that the data base of the analysis is satisfactory, therefore the results of the analysis are real.

In the analysis was used the Karl Pearson's Coefficient of Correlation (r) from SPSS in order to determine the relationship between linear related variables, followed by Principal Component Analysis and factor analysis to show the measure of the correlation among the selected economic variables as economic characters during the examined period in the score.

The results will show if the change in one is accompanied by the change in another variable, and aiming to proof that there are significant positive changes from FDI's on the selected socio-economic variables in Serbia. The outcome of this analysis is to provide preliminary picture about the impact of FDI on Serbian economy and their correlation with other socio-economic variables. Due to lack of data, authors were not able to perform other correlations affecting or impacting of the FDI in Serbian economy, such as FDI's expenditure on R\&D, level of education in manufacturing sector, etc.

\section{EMPIRICAL RESULTS AND DISCUSSION}

In the literature review, the data show that as the FDI inflows were increasing in Serbia, the GDP was increasing at the same time. At the same time, during the examined period the unemployment rate was decreasing in line with increased FDI inflows. The strength of the correlation is examined using and analysis are presented in the Table 1 bellow (The last number of the economic variables naming is ordering numbers given by author).

Table 1

Correlation matrix

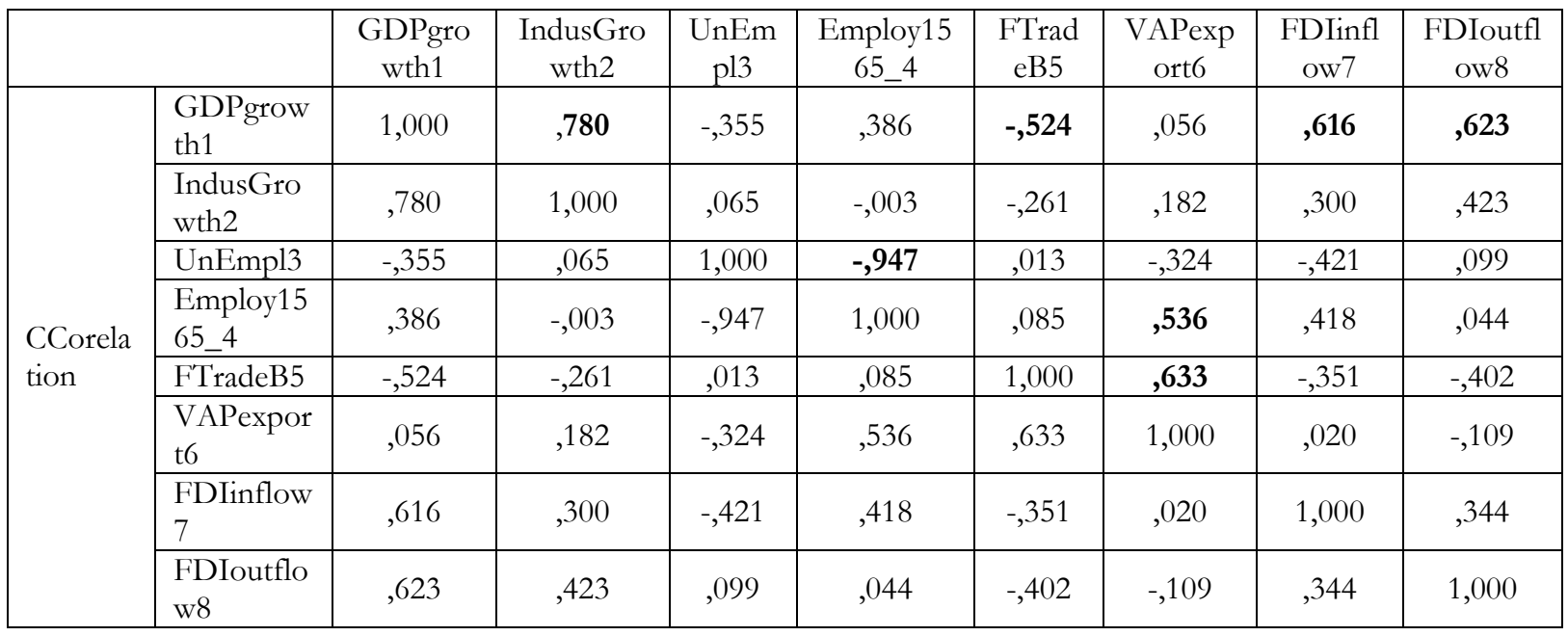

Source: Own calculation, based on the SPSS system, 2020. 
In case of the Republic of Serbia, correlations between the various indicators vary between being negligible and strong (Table 1). Some of them are with negative pre-sign, showing that most of the taken indicators are carrying reliable information which is giving additional value to the other indicators. There is very weak correlation between the FDI inflows and unemployment rate. Below results also suggest that there is very weak correlation between FDI inflows and increased GDP growth. As shown in Table 1, there are very strong correlations between unemployment rate and employment rate from age 15 to 65 by value of -0.947 . The minus as a sign means that the unemployment rate economic variable is in inverse ratio to the other variables. This is not surprising, given the fact these two are moving into different directions, i.e if unemployment rate is decreasing the employment rate from age 15 to 65 will increase.

The GDP growth has strong correlations with the industry growth, FDI inflow and FDI outflow. As the FDI inflows increase had positive and strong correlation to the GDP growth. At the same time GDP growth positively impacted industry growth in the examined period. GDP growth has middle strong correlation with foreign trade balance. Trade balance is a component of GDP. If other things remain equal, a surplus increases GDP and deficit reduces it. If this impact is strong enough, it gives rise to the traditional Keynesian multiplier effect with consumption moving in the same direction. Foreign trade balance has strong correlations with share of value-added products in export and employment rate from age 15 to 65 has middle strong correlation with share of value-added products in export.

Table 5

Rotated Component Matrix

\begin{tabular}{|l|c|c|c|}
\hline \multirow{2}{*}{} & \multicolumn{3}{|c|}{ Component } \\
\cline { 2 - 4 } & 1 & 2 & 3 \\
\hline GDPgrowth1 & $\mathbf{, 8 7 9}$ &, 394 &,- 161 \\
\hline IndusGrowth2 & $\mathbf{9 0 7}$ &,- 079 &, 151 \\
\hline UnEmpl3 &, 052 & $\mathbf{- , 9 7 0}$ &,- 079 \\
\hline Employ1565_4 &, 063 & $\mathbf{, 9 4 3}$ &, 259 \\
\hline FTradeB5 &,- 387 &,- 093 & $\mathbf{, 8 4 3}$ \\
\hline VAPexport6 &, 121 &, 307 & $\mathbf{9 0 7}$ \\
\hline FDIinflow7 &, 466 & $\mathbf{, 5 8 7}$ &,- 265 \\
\hline FDIoutflow8 & $\mathbf{, 7 4 0}$ &,- 017 &,- 234 \\
\hline
\end{tabular}

Extraction Method: Principal Component Analysis.

Rotation Method: Varimax with Kaiser Normalization.

Rotation converged in 5 iterations.

Source: Own calculation, based on the SPSS system, 2020.

The first component is at principle line " $\mathrm{X}$ ", and includes GDP growth, industrial growth and FDI outflow variables. The second component is at principle line "Y", and includes unemployment, employment from age 15 to 65 and FDI inflow. The third component is at principle line "Y" and includes foreign trade balance and share of value added products in the exports.

The importance of the score (coordinate system) is visibly shown below, in Figure 6. It shows the position of the examined years by score based on the values of the economic variables. Therefore, values of the variables shows the measures of the correlation among variables as socio-economic characters of the Serbian economy in the score (Figure 6).

Based on the first quarter of the score in Figure 6, in 2007, 2008, 2016 and 2018, when GDP growth, industrial growth and FDI outflow were growing or decreasing, at the same time unemployment, employment rate from age 15 to 65 and FDI inflow were moving into same direction, i.e. growing or decreasing. In the second quarter of the score in Figure 8, in 2009 and 2017, the GDP growth, industrial growth, and FDI outflow, are decreasing or decreasing slightly, while unemployment, employment rate 
from age 15 to 65 and FDI inflow remain increasing or slightly decreasing, similarly to the first quarter of the score.

In these two years it is visible alike movement trend of the analysed variables. In 2017 for example, when according to UNCTAD (2018) Serbia was among top 5 FDI inflows host economies among the transition economies, both the GDP growth and industrial growth decreased, while unemployment increased. This means that FDI are not the only influencer of the GDP growth and positive economic impact.

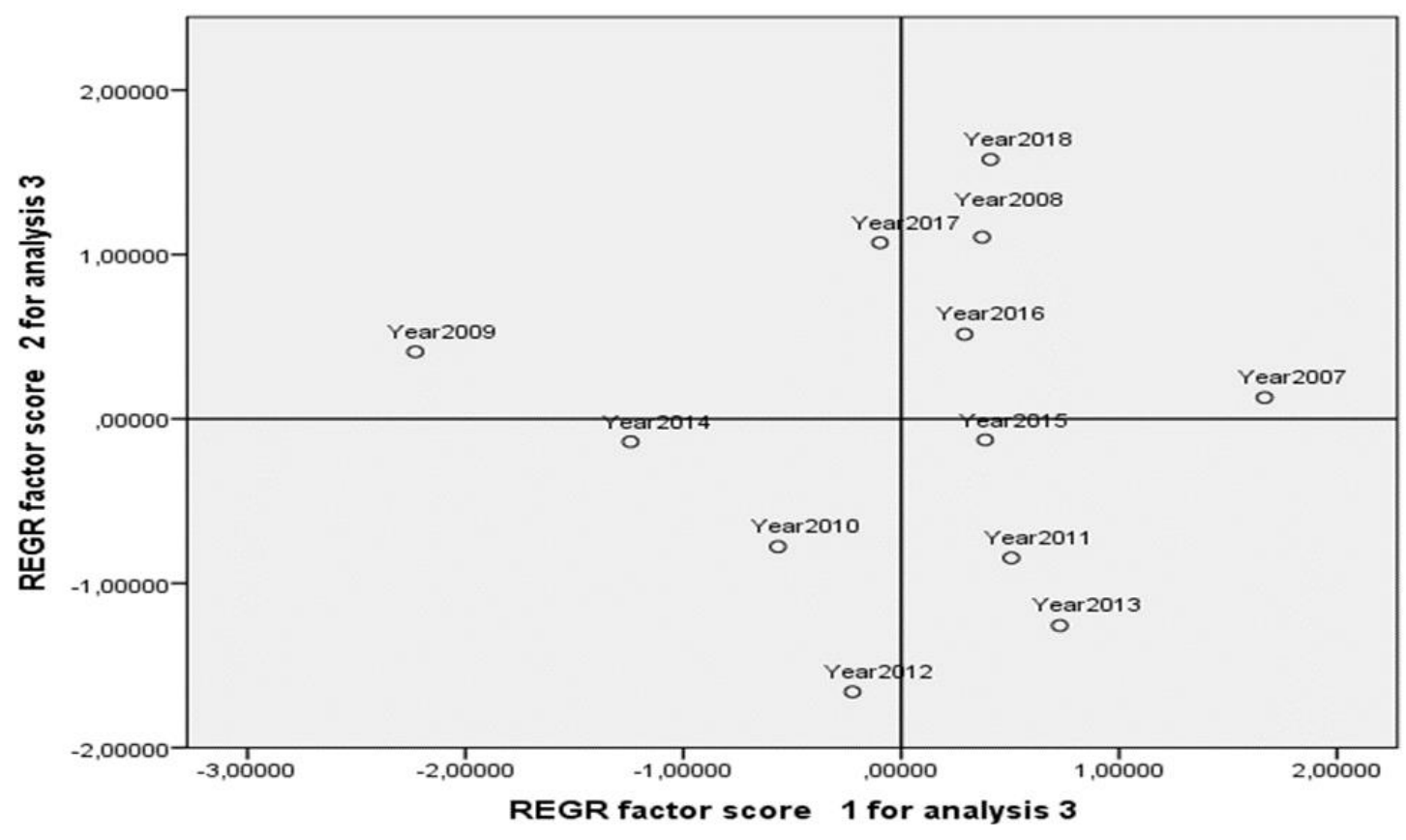

Line , $X ”=$ Component-1: GDP growth, Industrial Growth and FDI Outflow

Line „Y” = Component-2: Unemployment, Employment rate from age 15 to 65 and FDI Inflow

Figure 6. Factor analysis score 1 and 2 for selected variables

Source: Own calculation, based on the SPSS system, 2020.

In the third quarter of the score in Figure 6, in 2011, 2013 and 2015, the economic variables of GDP growth, industrial growth and FDI outflow are increasing or decreasing slightly, while the economic variables of unemployment, employment rate from age 15 to 65 and FDI inflow were decreasing or increasing slightly. In the fourth quarter of the score in Figure 6, in 2010, 2012 and 2014, all analysed economic variables GDP growth, industrial growth, FDI outflow, of unemployment, employment rate from age 15 to 65 and FDI inflow were decreasing or increasing slightly.

From the data it is notable that in 2012, 2013 and 2015, despite positive GDP and industrial growth, there has been FDI outflows, followed by decreased employment rate, from 37,9\% in 2010 to $35,8 \%$ in 2011. In 2010 it is notable that and FDI grew, the GDP grew as well, followed by unemployment decreasing and increased employment rate in Serbia. In 2012 and 2014, there was decrease in the economic activity, namely decreased FDI inflow, followed by decreased GDP growth. 


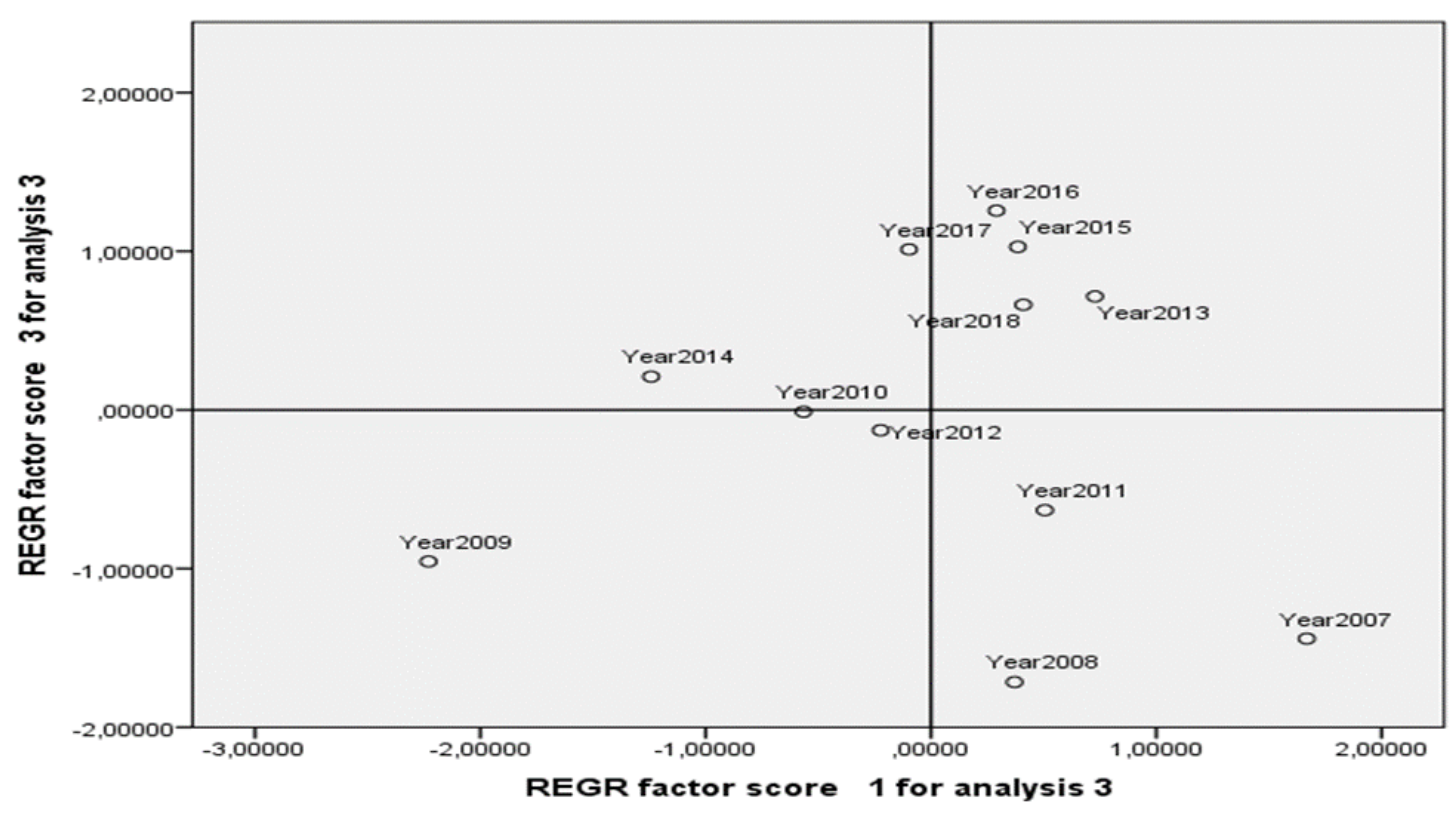

Line „X” = Component-1: GDP growth, Industrial Growth and FDI Outflow

Line „Y" $\mathrm{Y}$ " Component-3: Foreign trade balance and Share of value-added products in export

Figure 7. Factor analysis score 1 and 3 for selected variables

Source: Own calculation, based on the SPSS system, 2020.

In the first quarter of the score in Figure 8, in 2013, 2015, 2016 and 2018, when the GDP growth, industrial growth and FDI outflow were growing or decreasing, at the same time, foreign trade balance and share of value-added products in export were moving into same direction, i.e. growing or decreasing. In the second quarter of the score in Figure 8, in 2014 and 2017, the GDP growth, industrial growth and FDI outflow are decreasing or slightly decreasing, while the economic variables of foreign trade balance and share of value-added products in export, remain increasing or slightly decrease trend similarly to the first quarter of the score.

In 2014 and 2017, is visible alike movement trend of the analysed variables. In 2017 for example, when Serbia was among top 5 FDI inflows host economies among the transition economies UNCTAD (2018) and this movement had positive impact on the foreign trade balance and the export of the value added products. The most important reasons for Serbia's recent success in attracting FDI are economic reforms. Among these reforms is shortening the time required for registering a company registration, but also shortening time for issuing construction permit, which tales only 11 days. According to the Doing Business World Bank list, during the period between 2007 and 2017, Serbia constantly progressed with implementation reforms. The report showed that Serbia in 2014 made paying taxes costlier for companies by increasing the corporate income tax, while in 2015 transferring property was more difficult. However, this was simplified in 2017, showing government's continuous work towards simplification (World Bank, , 2019).

In the third quarter of the score in Figure 8, in 2007, 2008 and 2011, when the GDP growth, industrial growth and FDI outflow were increasing or slightly decreasing, the foreign trade balance and share of value-added products in export were decreasing or slightly increasing. In the fourth quarter of the score in Figure 8, in 2009 and 2010, when the GDP growth, industrial growth and FDI outflow were decreasing or slightly increasing, the foreign trade balance and share of value-added products in export were decreasing or slightly increasing same as the other economic variables. 
From the data it is notable that in the years 2007, 2008 and 2011, despite positive GDP and industrial growth, there has been worsen foreign trade balance. In 2010 it is notable that as the GDP grew, the trade balance stance was improved and the value of the value-added products exports got better.

\section{CONCLUSION}

The results show that despite increased inflow of FDI in Serbia, there is weak or no significant impact of the FDI inflows to decrease of the unemployment rate. However, the number of employed people in Serbia was increasing in the examined period. This effect is most probably, related to the fact that foreign companies tend to invest labor-intensive capacities, instead of in new and modern technologies, hence replacing the uneducated labor with advanced machinery. This can have negative implications in future, if this trend continues.

The results show that despite increased inflow of FDI in Serbia, there is weak correlation between FDI and decreasing unemployment, showing that FDI do not have strong impact on decreasing unemployment. This finding go in line with the statement from Strat et. al (2015), that state that the interdependencies among FDI and the employment or the unemployment rate can vary significantly from country to country. In case of Serbia, increased FDI does not have positive impact on decreasing the unemployment rate.

Moreover, there is evidence that FDI inflows in Serbia do not stimulate significant economic growth. One of the possible answers for increased GDP during the examined period could be linked to increased employment, domestic credit creation, and increased export due to increased foreign demand.

Results also show that there is strong correlation between increased FDI inflows and imports. Serbia has biggest deficit with China (due to imports of phones for cellular networks and laptops) and the Russian Federation (due to the import of energy products, primarily oil and gas). One of the reasons explaining this positive correlation is that new FDI capacities require more energy for operation and also more equipment.

The most important reasons for Serbia's recent success in attracting FDI are economic reforms. Among these reforms is shortening the time required for registering a company registration, but also shortening time for issuing construction permit, which takes only 11 days.

The country has still plenty to implement, in terms of improvement of the tax administration and interpretation of the tax regulation. EU reports are useful as they indicate that there is still corruption, and there is need for shifting the rule of law, increasing the efficiency of the judiciary and reducing political influence.

Serbia has still to do in order to tackle above mentioned findings. The government has to look into ways how to utilize FDI for further boosting the economy and growth.

\section{REFERENCES}

Ameer, W., \& Xu, H. (2017). The long-run effect of inward and outward foreign direct investment on economic growth: Evidence from developing economies. Review of Innovation and Competitiveness. A Journal of Economic and Social Research, 3(2), 5-24.

Basu, P., \& Guariglia, A. (2007). Foreign direct investment, inequality, and growth. Journal of Macroeconomics, 29(4), 824-39.

Bilan, Y., Vasylieva, T., Lyeonov, S., \& Tiutiunyk, I. (2019). Shadow Economy and its Impact on Demand at the Investment Market of the Country. Entrepreneurial Business and Economics Review, 7(2), 27-43.

Blanchard, O. (2011). Macroeconomics. Boston: Pearson Prentice Hall. 
Blomström, M., Kokko, A., \& Zejan, M. (2000). Foreign Direct Investment. Firm and host country Strategies. London: Macmillan Publishers.

Bobenič Hintošová, A., Bruothová, M., Kubíková, Z., \& Ručinský R. (2018). Determinants of foreign direct investment inflows: A case of the Visegrad countries. Journal of International Studies, 11(2), 222-235. doi:10.14254/2071-8330.2018/11-2/15

Botric, V., \& Škuflic, L. (2006). Main determinants of Foreign Direct Investment in the Southeast European countries. Transition Studies Review, 13, 359-377.

Caraballo, J.G., \& Jiang, X. (2016). Value-added erosion in global value chains: An empirical assessment. Journal of Economic Issues, 50(1), 288-296.

Caves, R.E. (1996). Multinational enterprise and economic analysis, Second edition. Cambridge: Cambridge University Press.

Deluca, D. (2004). Foreign Direct Investment. World 2000 (1,400): 1-30.

Draskovic, B. (2014). The crash of the industrial sector in Serbia, Are there any chances for re-industrialization? Institute for Economic Sciences, Belgrade: 107-133

Ernst \& Young (2018). European attractiveness survey, Russia, 2018. London: Ernst \& Young Global Limited.

Fazaalloh, A. M. (2019). Is foreign direct investment helpful to reduce income inequality in Indonesia?. Economics and Sociology, 12(3), 25-36. doi:10.14254/2071- 789X.2019/12-3/2

Herzer, D. (2008). The long-run relationship between outward FDI and domestic output: evidence from panel data. Economics Letters, 100 (1): 146-149

Ibreljić, I. \& Nuhanović, S. (2011). Strane direktne investicije u funkciji ekonomske transformacije ekonomske strukture zemalja jugoistočne Evrope. In: Zborniu radova Druga međunarodna naučna konferencija Ekonomija integracija - Izazovi i perspektive integracija zemalja jugoistočne Evrope. Tuzla: Ekonomski fakultet. [in Serbian]

IBM (2018). Global Location Trends, 2018 Annual Report: Getting ready for Globalization 4.0. Cambridge: IBM Institute for Business Value.

International Monetary Fund (2009). Non-financial corporations from emerging market economies and capital flows. BIS Quarterly Review December. Washington D.C.

Lyeonov, S., Pimonenko, T., Bilan, Y., Štreimikienė, D., \& Mentel, G. (2019). Assessment of green investments' impact on sustainable development: Linking gross domestic product per capita, greenhouse gas emissions and renewable energy. Energies, 12(20), 3891.

Markusen, J.R. (2004). Multinational firms and the theory of international trade. Cambridge: MIT press.

Melitz, M. J. \& Ottaviano, G. I. P. (2008). Market size, trade, and productivity. Review of Economic Studies, 75, $295-316$.

Ministry of Finance of Serbia. (2019). Various publications [statistics], Belgrade. Available at Ministry of Finance Database.

Nagy, J., Oláh, J., Erdei, E., Máté, D., \& Popp, J. (2018). The role and impact of industry 4.0 and the internet of things on the business strategy of the value chain-The case of Hungary. Sustainability, 10(10), 269-289. https://doi.org/10.3390/su10103491

National Bank of Serbia. (2019). Various publications [statistics], Belgrade. Available at NBS Database.

Reisen, H. \& Soto, M. (2001). Which types of capital inflows foster developing country growth?. International Finance, $4(1), 1-14$.

Rodríguez-Clare, A. (1996). Multinationals, linkages, and economic development. The American Economic Review, 86(4), 852-873.

Simionescu, M. (2016). Quarterly inflation rate target and forecasts in Romania. Economics, Management and Sustainability, 1(1), 6-13. doi:10.14254/jems.2016.1-1.1

Simionescu, M. (2018). Effects of European economic integration on foreign direct investment: The case of Romania. Economics and Sociology, 11(4), 96-105. doi:10.14254/2071-789X.2018/11-4/6

Soukiazis, E. \& Cerqueira, P.A. (Eds) (2012). Models of balance of payments constrained growth: History, theory and empirical evidence. Basingstoke: Palgrave MacMillan.

Statistical Office of Republic of Serbia. (2019). Various publications [statistics], Belgrade. Available at SORS Database. 
Strat, V. A., Davidescu, A., \& Paul, A. M. (2015). FDI and the unemployment-a causality analysis for the latest EU members. Procedia Economics and Finance, 23(2015), 635-643.

Tung, L. T. (2019). Does foreign direct investment really support private investment in an emerging economy? an empirical evidence in Vietnam. Montenegrin Journal of Economics, 15(1), 7-20. doi:10.14254/1800-5845/2019.151.1

UNCTAD (2013). World Investment Report 2013, Global value chains: Investment and trade for development. Geneva: United Nations Conference on Trade and Development.

UNCTAD. (2014). World Investment Report 2014, Investing in the SDGs: An Action Plan. Geneva: United Nations Conference on Trade and Development.

UNCTAD (2018). World Investment Report 2018, Investment and new industrial policies: Key messages and overview. Geneva: United Nations Conference on Trade and Development.

UNCTAD (2019). World Investment Report 2019, Special Economic Zones. Geneva: United Nations Conference on Trade and Development.

Uvalic, M. (2011). Insights from a Transition Economy: The case of Serbia. Institute of Economic Growth.

Vasylieva, T., Lyeonov, S., Lyulyov, O., \& Kyrychenko, K. (2018). Macroeconomic stability and its impact on the economic growth of the country. Montenegrin Journal of Economics, 14(1), 159-170. doi:10.14254/1800$5845 / 2018.14-1.12$

World Bank. (2019). Doing Business 2019: Training for reform, 16th edition. Washington DC: World Bank.

World Bank \& The Vienna Institute for International Economic Studies. Western Balkans Labor Market Trends 2019. March 2019.

Zugic, J. (2011). Foreign Direct Investment and global economic crisis in the Western Balkans, European perspectives. Journal on European Perspectives of the Western Balkans, 3(1), 69-90. 